\title{
Apel Kościołów w Polsce o ochronę stworzenia ${ }^{1}$
}

\section{Drodzy Bracia i Siostry!}

Kierujemy do Was ekumeniczny list, który jest apelem i prośbą o zachowanie stworzenia jako dzieła Bożego.

„Na początku Bóg stworzył niebo i ziemię” ( $\mathrm{Rdz} 1,1)$ - tymi uroczystymi słowami zaczyna się Pismo Święte. Świat nie powstał w wyniku ślepego przypadku, lecz z woli kochającego i mądrego Boga, podobnie jak człowiek, którego „Bóg stworzył na swój obraz” (por. Rdz 1,27). Potem, jak stwierdza Pismo, „Pan Bóg wziął człowieka i umieścił go w ogrodzie Eden, aby uprawiał go i doglądał” ( $\operatorname{Rdz} 2,15)$. Stwórca zaprasza człowieka do współpracy w trosce o swoje dzieło, służące wszystkim żywym istotom. Każda chrześcijańska tradycja podaje przykłady wybitnych ludzi, którzy z miłością traktowali całe Boże stworzenie. Niestety, nie zawsze jesteśmy wierni temu wezwaniu.

Produkujemy góry śmieci, trującą żywność, wycinamy lasy, otaczamy się światem z plastiku. Oślepienie żądzą zysku sprawia, że czyste strumienie zamieniamy w trujące ścieki, a bujne lasy i łany zboża w jałową i pustą ziemią, zaś cuda natury w zwały betonu. Żyjemy tak jakbyśmy byli ostatnim pokoleniem, które zamieszkuje Ziemię.

Apel sygnowany 16 stycznia 2013 r. przez przedstawicieli Kościołów zrzeszonych w Polskiej Radzie Ekumenicznej i Konferencji Episkopatu Polski. Podpisanie dokumentu nastąpiło w siedzibie Konferencji Episkopatu Polski w Warszawie. Źródło: http://episkopat.pl/ 
Ochrona środowiska to nie tylko techniczny problem równowagi ekologicznej, ale także problem moralny i duchowy współczesnego człowieka, który zapomina, że on sam i świat są Bożym stworzeniem.

Wielu chrześcijan na całym świecie angażuje się w konkretne programy służące ochronie Bożego stworzenia. Do najbardziej znanych należą projekty zarządzania budynkami w celu zmniejszenia zużycia energii elektrycznej i cieplnej, a także zmniejszenia produkcji odpadów, odzysku surowców, kompostowania itp.

Bracia i Siostry, trzeba propagować tę wrażliwość! Ufamy, że nasz apel spowoduje, że ludzie wierzący wpłyną na swoje otoczenie, by zlikwidować szkodliwe działania, takie jak wywożenie śmieci do lasu czy bezmyślne zaśmiecanie ulic, dróg i pól.

Nasz apel kierujemy także do władz państwowych i samorządowych. Wyrażamy troskę w kwestii prywatyzacji i komercjalizacji zasobów wody i przestrzeni publicznej.

Zachęcamy do kształtowania takiej polityki społecznej, która promuje bezpieczne przetwarzanie i utylizację trujących odpadów. Wzywamy przede wszystkim do:

- redukcji odpadów miejskich, odzyskiwania i utylizacji wysypisk śmieci, oczyszczania powietrza, wody i gleby;

- ochrony lasów oraz zagrożonych gatunków roślin i innych skarbów przyrody, do odtwarzania ekosystemów;

- stosowania technologii ekologicznych w przetwarzaniu i konserwacji żywności oraz produkcji opakowań;

- opracowania umów międzynarodowych dotyczących sprawiedliwego wykorzystywania zasobów morskich, które nie doprowadzą do zachwiania równowagi ekologicznej.

Przez zmartwychwstanie Jezusa Chrystusa i zesłanie Ducha Świętego Bóg objawił, że przezwycięża wszelkie zepsucie i śmierć. Chrześcijanin jest wezwany do ukazania swej wiary w Boga, Stwórcę i Pana wszechświata przez swe czyny. Dlatego zabiegamy o ochronę życia człowieka od samego poczęcia i o respektowanie jego godności. Apelujemy o wspieranie takiej polityki społecznej, która pozwala na krzewienie 
życia wszędzie tam, gdzie radykalnie zmniejsza się przyrost naturalny. Świat potrzebuje takiego świadectwa nie tylko tych nielicznych, zaangażowanych w ochronę środowiska, ale wszystkich uczniów Chrystusa. W zrozumieniu tych procesów pomocną dla chrześcijan może stać się dynamicznie rozwijająca się refleksja biblijna i teologiczna na temat stworzenia.

Nasze wspólne działania winny wyrażać prawdę o potrzebie roztropnego i umiarkowanego postępowania we wszystkim, co jest związane z naszym środowiskiem. Mądra asceza wyraża się unikaniem nadmiernej konsumpcji, odpowiedzialnym korzystaniem $z$ dóbr naturalnych oraz rezygnacją z produkowania i gromadzenia nadmiaru przedmiotów i opakowań. Jednym z jej przejawów jest coraz bardziej zapominany post, który jako samoograniczanie własnych pożądań, staje się narzędziem duchowej przemiany i pomocy potrzebującym. Zlecone nam przez Stwórcę zadanie panowania nad rzeczami służy temu, aby nie zapanowały one nad nami.

Bracia i Siostry, żyjąc dzisiaj, pomyślmy o jutrze. Pomyślmy o tym, że my i całe stworzenie jesteśmy powołani do życia w rzeczywistości opisanej w ostatniej księdze Biblii jako „nowe niebiosa i nowa ziemia” (Ap 21,1). Dlatego codziennie dokonujmy odpowiedzialnych wyborów oszczędzających energię i zasoby ziemi oraz szanujmy wszystko, co żyje. Nawet niewielkie, ale konsekwentne działania przyniosą ogromny skutek w ochronie całego stworzenia, które, jak czytamy w pierwszej księdze Pisma Świętego, „Bóg uczynił bardzo dobre” (por. Rdz 1,31).

Warszawa, 16 stycznia 2013 r.

W imieniu Kościołów zrzeszonych w Polskiej Radzie Ekumenicznej i Konferencji Episkopatu Polski:

- ks. prezbiter Gustaw Cieślar (Przewodniczący Rady Kościoła Chrześcijan Baptystów w RP);

- ks. bp Jerzy Samiec (Biskup Kościoła Ewangelicko-Augsburskiego w RP); 
- ks. bp Edward Puślecki (Biskup Kościoła Ewangelicko-Metodystycznego w RP);

- ks. bp Marek Izdebski (Biskup Kościoła Ewangelicko-Reformowanego w RP);

- ks. bp Wiktor Wysoczański (Biskup Kościoła Polskokatolickiego w RP);

- ks. bp Ludwik Jabłoński (Biskup Naczelny Kościoła Starokatolickiego Mariawitów w RP)

- Metropolita Sawa (Prawosławny Metropolita Warszawski i Całej Polski);

- ks. abp Józef Michalik (Przewodniczący Konferencji Episkopatu Polski). 